\title{
Title of Abstract: \\ On-Line Thermal Barrier Coating (TBC) Monitor for Real-Time Failure Protection and Life Maximization
}

\author{
Dennis H. LeMieux, Materials Engineering / Non-Destructive Testing, \\ Siemens Westinghouse Power Corporation \\ 4400 Alafaya Trail, MC Q3-031, Orlando, FL 32826, USA \\ Phone: +1407 7365137 \\ e-mail: dennis.lemieux@siemens.com \\ Vinay Jonnalagadda, Materials Engineering / Non-Destructive Testing, \\ Siemens Westinghouse Power Corporation \\ 4400 Alafaya Trail, MC Q3-031, Orlando, FL 32826, USA \\ Phone: +1407 7366810 \\ e-mail: vinay.jonnalagadda@siemens.com
}

\begin{abstract}
:
Monitoring of mission critical engine parts during gas turbine operation is now possible by combining innovative access port design, high-speed infrared imagery, a tailor-made overall control and image evaluation system, and related TBC lifing models. The need for such monitoring has become more critical in recent years as engine firing temperatures have risen and the potential impact of part failure has grown. In particular, the need to guard against the loss of TBC has become an important factor for maximizing turbine availability and for minimizing commercial risk. This On-Line TBC Blade Monitor will not only help insure the safe operation of a gas turbine, but also provide the opportunity to extend the life of blades beyond the nominal operating hours, based on real-time and historical images that clearly prove the integrity of the thermal barrier coating.

This paper will present an overview of an On-Line TBC Blade Monitoring system, which is able to capture two-dimensional quantitative infrared images of row-1 blades during full engine operation. This system, which was successfully tested on our $200 \mathrm{MW}$ class gas turbine at full load, was developed by a team of Siemens Westinghouse Power Corporation Engineering and Diagnostics experts in cooperation with Siemens Corporate Research under the sponsorship of the U.S. Department of Energy's National Energy Laboratory.
\end{abstract}

\section{Keywords:}

Infrared Thermography, Thermal Barrier Coating, Gas Turbine Engines, Condition Monitoring, Image Evaluation 
http://dx.doi.org/10.21611/qirt.2006.043 